\title{
Clinicopathological and prognostic factors for long-term survival in Chinese patients with metastatic renal cell carcinoma treated with sorafenib: a single-center retrospective study
}

\author{
Hai-Liang Zhang ${ }^{1,2, *}$, Xiao-Jian Qin ${ }^{1,2, *}$, Hong-Kai Wang ${ }^{1,2}$, Wei-Jie Gu ${ }^{1,2}$, \\ Chun-Guang Ma ${ }^{1,2}$, Guo-Hai Shi ${ }^{1,2}$, Liang-Ping Zhou ${ }^{2,3}$, Ding-Wei $\mathrm{Ye}^{1,2}$ \\ ${ }^{1}$ Department of Urology, Fudan University, Shanghai Cancer Center, Shanghai 200032, P.R. China \\ ${ }^{2}$ Department of Oncology, Shanghai Medical College, Fudan University, Shanghai 200032, P.R. China \\ ${ }^{3}$ Department of Radiology, Fudan University, Shanghai Cancer Center, Shanghai 200032, P.R. China \\ *These authors have contributed equally to this work \\ Correspondence to: \\ Ding-Wei Ye, e-mail: wyeli@163.com \\ Keywords: sorafenib, advanced RCC, China, overall survival, prognostic factors \\ Received: May 08, 2015 \\ Accepted: October 01, 2015 \\ Published: October 14, 2015
}

\section{ABSTRACT}

Data on long-term survival and prognostic significance of demographic factors and adverse events (AEs) associated with sorafenib, an orally administered multikinase inhibitor in Chinese population with advanced renal cell carcinoma (RCC) are limited. Outcome data from adult patients $(n=256)$ with advanced RCC who received sorafenib (400 $\mathrm{mg}$ twice daily) either as first-line or second-line therapy between April 2006 and May 2013 were analyzed retrospectively. The primary endpoint was median overall survival (OS), determined to be 22.2 (95\% CI: 17.1-27.4) months, and the secondary endpoint was overall median progression-free survival (PFS), determined to be 13.6 (95\% CI: 10.7-16.4) months at a median follow-up time of 61.8 (95\% CI: 16.2-97.4) months. Analysis of the incidence of AEs revealed the most common side effect as hand-foot skin reactions $(60.5 \%)$ followed by diarrhea $(38.7 \%)$, fatigue $(35.5 \%)$, alopecia $(34.0 \%)$, rash $(24.6 \%)$, hypertension $(21.5 \%)$ and gingival hemorrhage (21.1\%). Multivariate regression analysis revealed older age ( $\geq 58$ years), lower Memorial Sloan-Kettering Cancer Center score, time from nephrectomy to sorafenib treatment, number of metastatic tumors and best response as significant and independent demographic predictors for improved PFS and/or OS $(p \leq 0.05)$. Alopecia was identified as a significant and independent predictor of increased OS, whereas vomiting and weight loss were identified as significant predictors of decreased OS $(p \leq 0.05)$. Sorafenib significantly improved OS and PFS in Chinese patients with advanced RCC. Considering the identified significant prognostic demographic factors along with the advocated prognostic manageable AEs while identifying treatment strategy may help clinicians select the best treatment modality and better predict survival in these patients.

\section{INTRODUCTION}

Renal cell carcinoma (RCC) is a heterogeneous group of tumors with distinct genetic and metabolic defects. It encompasses diverse clinical, histopathological, and molecular factors, which also have a role in differential prognosis and therapeutic responses [1]. Recent advances in the understanding of molecular biology and the cytogenetics of advanced RCC have provided unique insights into the underlying mechanisms contributing to its histological and biological diversity [2]. Consequently, targeted agents, including inhibitors of tyrosine kinase, vascular endothelial growth factor (VEGF), and mammalian target of rapamycin (mTOR) have revolutionized the therapeutic landscape in the management of patients with metastatic RCC (mRCC) 
$[3,4]$. The efficacy of sorafenib, a multikinase inhibitor, in RCC has been previously confirmed in Phase II and Phase III trials, leading to its approval by the US Food and Drug Administration in December 2005 as the first targeted agent to show clinical activity in RCC as reviewed earlier [5]. Since then, an array of targeted drugs (tyrosine kinase inhibitors sunitinib, axitinib, and pazopanib; the VEGF monoclonal antibody bevacizumab; and the mTORs temsirolimus and everolimus) have been introduced and are now approved for clinical use [3, 6, 7]. Previous studies, including the pivotal TARGET trial, have demonstrated promising evidence for sorafenib administered at a dose of $400 \mathrm{mg}$ twice daily both as a first-line and second-line therapy for advanced RCC primarily in the western population $[7,8]$. These studies have shown varying improvement in progression-free survival (PFS), overall response rates, overall survival (OS), tolerance, and quality of life compared with other investigational agents including interferon, IFN $\alpha 2 \mathrm{a}$, tivozanib, temsirolimus, AMG 386, and axitinib [8-11].

There has been a considerable increase in the incidence of RCC and the associated mortality rates in China, which were estimated to be $2.2 \%$ and $1.2 \%$, respectively, for all new cases of cancers excluding non-melanoma skin cancer according to GLOBOCAN worldwide estimates of cancer incidence published by the International Agency for Research on Cancer for 2012 [12]. As reviewed earlier, previous studies have shown sorafenib as a potential targeted agent with a manageable toxicity profile when used even at higher doses (1200-1600 mg/day) or in combination with other agents such as interferon, bevacizumab, temsirolimus, gemcitabine, fluorouracil, and cisplatin for treating Chinese patients with RCC [5]. Sorafenib was found to be more effective in the Chinese population when compared with the western population both as first-line and second-line treatment after failure of treatment with cytokine in patients with advanced RCC, but with a relatively higher rate of adverse events (AEs), particularly hand-foot skin reactions and alopecia. [5] However, data on the long-term survival of Chinese patients with advanced RCC treated with sorafenib are limited. The present study determined the potential of sorafenib treatment on the long-term survival in Chinese patients with metastatic RCC (mRCC) and further evaluated the prognostic factors associated with OS and/or PFS.

\section{RESULTS}

\section{Baseline demographics}

Between April 2006 and May 2013, a total of 317 patients with $\mathrm{mRCC}$ treated with sorafenib were screened at the Department of Urology, Fudan University, Shanghai Cancer Center. In all, 256 patients (age 19-89 years, median 58 years) met the inclusion criteria and were considered for the analysis. The other 61 patients were lost to follow-up. The baseline demographics and clinical characteristics are summarized in Table 1. Overall, 53.1\% of the patients were aged $\geq 58$ years and $71.5 \%$ were

\section{Table 1: Baseline demographic and clinical characteristics of the Chinese patients with RCC treated with sorafenib.}

\begin{tabular}{l}
\hline Characteristics \\
\begin{tabular}{|c|c|}
\hline Gender & Number (Percentage) $N=\mathbf{2 5 6}$ \\
\hline Male & $183(71.5 \%)$ \\
\hline Female & $73(28.5 \%)$ \\
\hline Age $($ Years $)$ & $136(53.1 \%)$ \\
\hline$\geq 58$ & $120(46.9 \%)$ \\
\hline$<58$ & \\
\hline BMI $($ Mean $\pm \mathrm{SD})\left(\mathrm{kg} / \mathrm{m}^{2}\right)$ & $125(48.8 \%)$ \\
\hline$\geq 23.1$ & $131(51.2 \%)$ \\
\hline$<23.1$ & \\
\hline MSKCC score & $74(28.9 \%)$ \\
\hline Low risk & $130(50.8 \%)$ \\
\hline Intermediate risk & $52(20.3 \%)$ \\
\hline High risk & \\
\hline
\end{tabular}
\end{tabular}

(Continued) 


\begin{tabular}{|c|c|}
\hline \multicolumn{2}{|l|}{ ECOG performance status } \\
\hline 0 & $104(40.6 \%)$ \\
\hline 1 & $116(45.3 \%)$ \\
\hline 2 & $33(12.9 \%)$ \\
\hline 3 & $3(1.2 \%)$ \\
\hline \multicolumn{2}{|l|}{ Histology } \\
\hline Clear cell subtype & $201(78.5 \%)$ \\
\hline Non-clear cell subtypes & $55(21.5 \%)$ \\
\hline \multicolumn{2}{|l|}{ Tumor nucleus grade } \\
\hline $1-2$ & $68(26.6 \%)$ \\
\hline $3-4$ & $188(73.4 \%)$ \\
\hline \multicolumn{2}{|l|}{ Previous nephrectomy } \\
\hline Yes & $203(79.3 \%)$ \\
\hline No & $53(20.7 \%)$ \\
\hline \multicolumn{2}{|c|}{$\begin{array}{l}\text { Time from nephrectomy to sorafenib treatment Metastatic } \\
\text { disease at diagnosis }\end{array}$} \\
\hline No palliative nephrectomy & $53(20.7 \%)$ \\
\hline Palliative nephrectomy & $41(16.0 \%)$ \\
\hline \multicolumn{2}{|c|}{ Metastatic disease after radical nephrectomy } \\
\hline$\geq 12$ months & $98(38.3 \%)$ \\
\hline$<12$ months & $64(25.0 \%)$ \\
\hline \multicolumn{2}{|l|}{ Metastatic organs } \\
\hline 1 & $122(47.7 \%)$ \\
\hline 2 & $99(38.7 \%)$ \\
\hline 3 & $29(11.3 \%)$ \\
\hline 4 & $6(2.3 \%)$ \\
\hline \multicolumn{2}{|l|}{ Previous systemic therapy } \\
\hline None & $187(73.1 \%)$ \\
\hline Cytokine & $60(23.4 \%)$ \\
\hline Sunitinib & $9(3.5 \%)$ \\
\hline
\end{tabular}

BMI, body mass index; ECOG, Eastern Cooperative Oncology Group; MSKCC, Memorial Sloan-Kettering Cancer Center; OS, overall survival; PFS, progression-free survival; RCC, renal cell carcinoma.

male. Almost half of the patients included in this study presented with an Memorial Sloan-Kettering Cancer Center (MSKCC) score for intermediate risk (50.8\%) and the Eastern Cooperative Oncology Group (ECOG) performance status was mostly $0(40.6 \%)$ or $1(45.3 \%)$. The type of RCC was histologically classified as clear cell subtype in majority of the patients $(78.5 \%)$, tumor nucleus grade of 3-4 (73.4\%), and predominantly single tumor site $(47.7 \%)$. About $79.3 \%$ of the included patients had undergone previous nephrectomy and $73.1 \%$ of the patients did not receive any previous systemic therapy.

\section{Best tumor response}

Best tumor response was primarily characterized as complete remission (CR), partial remission (PR), stable disease (SD), and progressive disease (PD), respectively, in $2(0.8 \%), 45(17.6 \%), 176(68.7 \%)$, and $33(12.9 \%)$ of the included patients. Clinical benefit rate (CR, PR, and SD) was found to be $87.1 \%$, while object response rate (CR and PR) was found to be $18.4 \%$. Between the first sorafenib treatment and the study cut-off date (May 31, 2014), a total of 176 patients reached PD and 153 patients 
died after a median follow-up time of 61.8 (16.2-97.4) months. The Kaplan-Meier estimates for PFS and OS are presented in Figure 1A and Figure 1B respectively. Overall median PFS was 13.6 (95\% CI: 10.7-16.4) months and the median OS was 22.2 (95\% CI: 17.1-27.4) months.

\section{Prognostic factors for survival}

Univariate analysis was used to screen for potential prognostic factors such as gender, age, body mass index

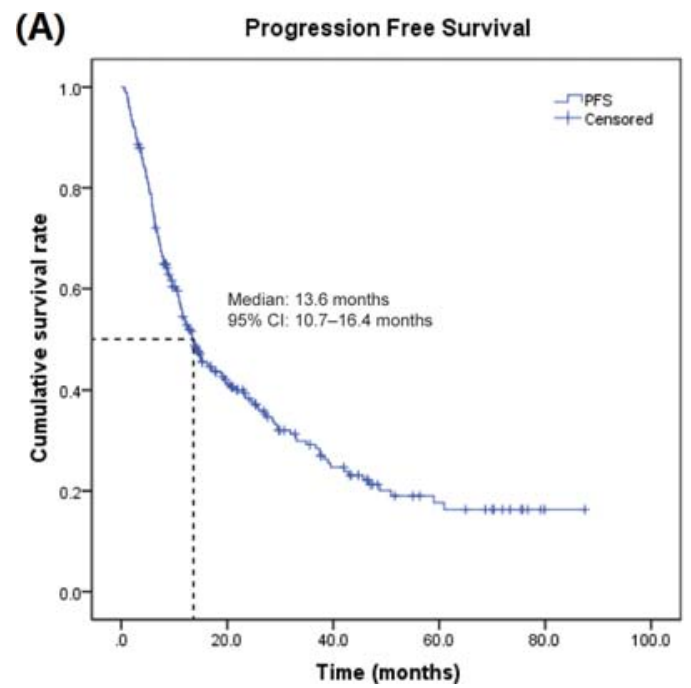

(BMI), MSKCC score, ECOG performance status, histology, tumor nucleus grade, previous nephrectomy, time from nephrectomy to sorafenib treatment, number of metastatic organs, previous systemic therapy, and best response (Table 2). The probable prognostic factors with a $p<0.1$ including age, BMI, ECOG performance status, MSKCC score, time from nephrectomy to sorafenib treatment, histology, tumor nucleus grade, number of metastatic organs, and best response were entered into the multivariate Cox proportional hazard regression

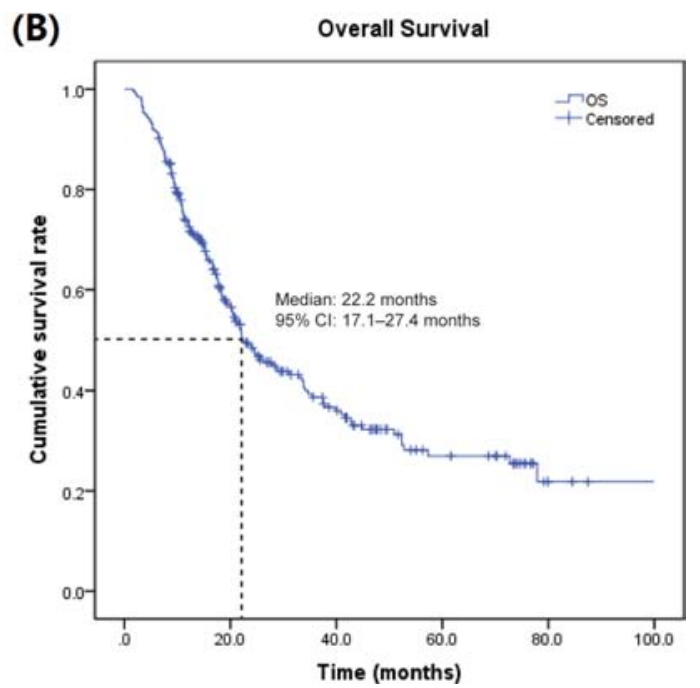

Figure 1: Kaplan-Meir estimates of PFS and OS in Chinese patients with mRCC treated with sorafenib. $\mathrm{mRCC}$, metastatic renal cell carcinoma; OS, overall survival; PFS, progression free survival.

Table 2: Baseline prognostic factors of PFS and OS in Chinese patients with $\mathrm{mRCC}$ treated with sorafenib.

\begin{tabular}{|c|c|c|c|c|}
\hline Characteristics & $\begin{array}{c}\text { Median PFS (95\% CI) } \\
\text { (Months) }\end{array}$ & $p$ value & $\begin{array}{c}\text { Median OS (95\% CI) } \\
\text { (Months) }\end{array}$ & $p$ value \\
\hline \multicolumn{5}{|l|}{ Gender } \\
\hline Male & $14.3(9.7,18.9)$ & 0.163 & $23.4(14.0,32.8)$ & 0.368 \\
\hline Female & $11.1(9.7,12.4)$ & & $22.2(14.4,30.1)$ & \\
\hline \multicolumn{5}{|l|}{ Age (Years) } \\
\hline$\geq 58$ & $23.3(13.9,32.7)$ & 0.020 & $33.8(22.7,44.9)$ & 0.082 \\
\hline$<58$ & $10.9(9.0,12.8)$ & & $20.4(16.9,24.0)$ & \\
\hline \multicolumn{5}{|l|}{$\begin{array}{l}\text { BMI }(\text { Mean } \pm \text { SD }) \\
\left(\mathrm{kg} / \mathrm{m}^{2}\right)\end{array}$} \\
\hline$\geq 23.1$ & $14.1(11.2,17.5)$ & 0.263 & $33.6(22.0,45.2)$ & 0.050 \\
\hline$<23.1$ & $11.5(6.7,16.0)$ & & $21.1(18.1,25.6)$ & \\
\hline \multicolumn{5}{|l|}{ MSKCC score } \\
\hline Low risk & $42.1(17.8,66.3)$ & $<0.001$ & 97.2 (NA, NA) & $<0.001$ \\
\hline Intermediate risk & $11.6(8.6,14.7)$ & & $23.4(20.2,26.6)$ & \\
\hline
\end{tabular}

(Continued) 


\begin{tabular}{|c|c|c|c|c|}
\hline Characteristics & $\begin{array}{c}\text { Median PFS (95\% CI) } \\
\text { (Months) }\end{array}$ & $p$ value & $\begin{array}{c}\text { Median OS (95\% CI) } \\
\text { (Months) }\end{array}$ & $p$ value \\
\hline High risk & $5.1(3.4,6.8)$ & & $8.8(6.9,10.7)$ & \\
\hline \multicolumn{5}{|l|}{$\begin{array}{l}\text { ECOG performance } \\
\text { status }\end{array}$} \\
\hline 0 & $25.7(17.1,34.3)$ & $<0.001$ & $44.9(29.4,60.4)$ & $<0.001$ \\
\hline 1 & $11.5(8.5,14.5)$ & & $20.7(17.6,23.7)$ & \\
\hline 2 & $5.9(0.7,11.1)$ & & $10.8(8.1,13.5)$ & \\
\hline 3 & $3.4(2.3,4.4)$ & & $8.8(6.5,11.0)$ & \\
\hline \multicolumn{5}{|l|}{ Histology } \\
\hline Clear cell subtype & $16.3(10.0,22.6)$ & 0.001 & $28.7(17.7,37.7)$ & $<0.001$ \\
\hline $\begin{array}{l}\text { Non-clear cell } \\
\text { subtypes }\end{array}$ & $6.9(5.9,8.2)$ & & $11.3(4.7,17.8)$ & \\
\hline \multicolumn{5}{|l|}{ Tumor nucleus grade } \\
\hline $1-2$ & $35.0(24.2,45.8)$ & $<0.001$ & $52.4(26.5,78.2)$ & $<0.001$ \\
\hline $3-4$ & $10.8(9.0,12.7)$ & & $19.4(16.2,22.6)$ & \\
\hline \multicolumn{5}{|l|}{ Previous nephrectomy } \\
\hline Yes & $13.6(7.8,19.4)$ & 0.800 & $24.1(15.5,32.7)$ & 0.041 \\
\hline No & $13.4(10.0,16.8)$ & & $18.4(11.5,25.3)$ & \\
\hline \multicolumn{5}{|l|}{$\begin{array}{l}\text { Time from } \\
\text { nephrectomy to } \\
\text { sorafenib treatment }\end{array}$} \\
\hline \multicolumn{5}{|l|}{$\begin{array}{l}\text { Metastatic disease at } \\
\text { diagnosis }\end{array}$} \\
\hline $\begin{array}{l}\text { No palliative } \\
\text { nephrectomy }\end{array}$ & $13.8(7.9,19.7)$ & $<0.001$ & $18.4(10.3,26.5)$ & $<0.001$ \\
\hline $\begin{array}{l}\text { Palliative } \\
\text { nephrectomy }\end{array}$ & $11.3(5.5,17.0)$ & & $23.4(9.8,36.9)$ & \\
\hline \multicolumn{5}{|l|}{$\begin{array}{l}\text { Metastatic disease } \\
\text { after radical } \\
\text { nephrectomy }\end{array}$} \\
\hline$\geq 12$ months & $27.3(15.2,39.5)$ & & $77.9(30.1,125.7)$ & \\
\hline$<12$ months & $7.1(5.5,8.7)$ & & $16.8(12.1,21.5)$ & \\
\hline \multicolumn{5}{|l|}{ Metastatic organs } \\
\hline 1 & $28.8(20.8,36.9)$ & $<0.001$ & $42.7(27.1,58.2)$ & $<0.001$ \\
\hline 2 & $10.5(7.5,13.6)$ & & $18.7(15.7,21.7)$ & \\
\hline 3 & $7.5(3.3,11.7)$ & & $11.1(7.0,15.1)$ & \\
\hline 4 & $4.0(2.9,5.2)$ & & $5.4(3.4,7.4)$ & \\
\hline \multicolumn{5}{|l|}{$\begin{array}{l}\text { Previous systemic } \\
\text { therapy }\end{array}$} \\
\hline None & $14.1(4.6,23.5)$ & 0.109 & $24.9(17.4,32.4)$ & 0.246 \\
\hline Cytokine & $13.6(10.3,16.8)$ & & $22.4(16.2,28.7)$ & \\
\hline Sunitinib & $6.3(3.5,9.1)$ & & $11.3(9.6,13.0)$ & \\
\hline Best response & & & & \\
\hline
\end{tabular}

(Continued) 


\begin{tabular}{|c|c|c|c|c|}
\hline \multicolumn{1}{c}{$\begin{array}{c}\text { Median PFS (95\% CI) } \\
\text { (Months) }\end{array}$} & \multicolumn{1}{c}{$p$ value } & $\begin{array}{c}\text { Median OS (95\% CI) } \\
\text { (Months) }\end{array}$ & $p$ value \\
\hline CR & 46.7 (NA, NA) & $<0.001$ & Not reached & $<0.001$ \\
\hline PR & $25.0(17.8,32.2)$ & & $42.7(26.5,59.7)$ & \\
\hline SD & $13.7(10.1,17.3)$ & & $22.4(19.3,22.7)$ & \\
\hline PD & $2.1(1.7,2.5)$ & & $6.7(5.4,7.9)$ & \\
\hline
\end{tabular}

BMI, body mass index; CR, complete remission; ECOG, Eastern Cooperative Oncology Group; MSKCC, Memorial SloanKettering Cancer Center; NA, not applicable as was not achieved; OS, overall survival; PD, disease progression; PFS, progression-free survival; PR, partial remission; SD, stable disease.

model for analysis. Older age, lower MSKCC score, lower number of metastatic organs, and best tumor response were found to be significant and independent predictors for improved PFS and OS. Additionally, time from nephrectomy to sorafenib treatment also significantly predicted improved PFS but not OS $(p \leq 0.05$; Figure 2A and 2B).

\section{Adverse events}

Analysis of AEs in the included patients revealed the most common side effect as hand-foot skin reactions (60.5\%) followed by diarrhea (38.7\%), fatigue $(35.5 \%)$, alopecia (34.0\%), rash (24.6\%), hypertension (21.5\%), and gingival hemorrhage (21.1\%). The AEs recorded in $>1 \%$ of the included patients during the study period and their grades are listed in Table 3. Univariate analysis revealed the incidence of most of the commonly encountered AEs such as hand-foot skin reactions, alopecia, rash, diarrhea, and hypertension to be associated with increased OS, while other AEs such as vomiting, albuminuria, and weight loss were associated with decreased OS $(p \leq 0.05)$ (Table 4). The probable prognostic factors with a $p<0.1$ were entered into the multivariate Cox proportional regression model for analysis. Multivariate analysis revealed alopecia to be a significant and independent predictor for increased OS, whereas vomiting and weight loss were identified as significant predictors for decreased OS $(p \leq 0.05)$ (Figure 3$)$.

\section{DISCUSSION}

The efficacy and tolerability of sorafenib in the treatment of advanced RCC is well established in the global population, while the data on long-term survival are primarily from the western population $[5,7,8$, 13-21]. Long-term survival rates following sorafenib treatment are, however, limited in patients of Asian origin, particularly China, wherein there is an increasing incidence of RCC contributing to increased mortality and reduced survival. The present retrospective study contributes valuable insights into the long-term survival of Chinese patients with advanced RCC treated with sorafenib as first-line or second-line therapy.

The findings from our study suggest that sorafenib is effective in improving the OS and PFS in Chinese patients with advanced RCC both as first-line and second-line treatment, with a manageable toxicity profile. Median OS was found to be 22.2 months in our study, which seemed to be higher than that reported in earlier studies in the Chinese and western populations (11.7-17.8 months). Median PFS (13.6 months) and clinical benefit rate ([CR+PR+SD], 87.1\%) were also found to be consistent with the previous reports from China (PFS, 9.6-15 months; clinical benefit rate, $80 \%-88 \%$ ) and appeared to be greatly improved than those reported in western populations (PFS, 5.5-6.6 months; clinical benefit rate, $84 \%-85 \%)$. The objective response rate ([CR+PR], 18.4\%) was similar or lower than that reported in previous studies from China $(16.7 \%-36.6 \%)$, but was higher than the reports from the western populations $(4.0 \%-10.2 \%)[5,13-20]$. However, the baseline demographics and clinical characteristics of the patients included in this investigation were different from the previous western studies [8-11]. The observed improvements in survival, therefore, need to be further validated in future trials or propensity matched studies comparing the efficacy of sorafenib between Chinese patients and Western populations. Ethnic differences were earlier demonstrated to influence incidence rates and survival rates in RCC [22]. Overall, the better clinical outcomes of sorafenib treatment in Chinese patients with advanced RCC compared with patients of western origin are probably due to the difference in ethnicity and the associated differences in molecular features as reviewed earlier [5]. Polymorphism of cancer susceptibility genes, which in turn may be associated with the ethnicity, was earlier suggested as a potential predictor of outcome and toxicity of tyrosine kinase inhibitors including sorafenib $[5,23,24]$.

The multivariate analysis of prognostic demographic factors revealed older age ( $\geq 58$ years) to be a significant predictor of improved PFS and OS in patients with 


\section{(A) Progression Free Survival}

\begin{tabular}{llr}
\multicolumn{1}{c}{ Variables } & $\boldsymbol{p}$ value & Hazard Ratio [95\% Cl] \\
\hline Age & 0.018 & $0.685[0.500-0.938]$ \\
$\mathrm{BMI}$ & 0.593 & $1.088[0.798-1.483]$ \\
ECOG & 0.898 & $1.017[0.786-1.316]$ \\
MSKCC & 0.000 & $2.612[1.937-3.522]$ \\
Time from nephrectomy to sorafenib Rx & 0.006 & $1.761[1.172-2.646]$ \\
Subtype & 0.494 & $1.135[0.789-1.632]$ \\
Grade & 0.175 & $1.338[0.879-2.039]$ \\
Number of metastatic organs & 0.000 & $1.485[1.200-1.837]$ \\
Best response & 0.000 & $2.731[1.877-3.975]$
\end{tabular}

\section{(B) Overall Survival}

\begin{tabular}{|c|c|c|c|}
\hline Variables & $p$ value & \multicolumn{2}{|c|}{ Hazard Ratio $[95 \% \mathrm{CI}]$} \\
\hline Age & 0.013 & & $0.648[0.460-0.914]$ \\
\hline BMI & 0.605 & - & $0.915[0.654-1.281]$ \\
\hline ECOG & 0.109 & 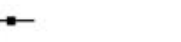 & $1.255[0.951-1.656]$ \\
\hline MSKCC & 0.000 & $\rightarrow-$ & $3.171[2.292-4.388]$ \\
\hline Time from nephrectomy to sorafenib Rx & 0.394 & 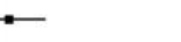 & $1.205[0.785-1.852]$ \\
\hline Subtype & 0.136 & $\rightarrow-$ & $1.341[0.912-1.971]$ \\
\hline Grade & 0.207 & & $1.347[0.848-2.140]$ \\
\hline Number of metastatic organs & 0.000 & $\rightarrow$ & $1.529[1.210-1.932]$ \\
\hline \multirow[t]{2}{*}{ Best response } & 0.000 & $\longrightarrow$ & $2.762[1.866-4.089]$ \\
\hline & & 3 & \\
\hline
\end{tabular}

Figure 2: Forest plots displaying multivariate Cox analysis of demographic variables prognostic to PFS and OS in Chinese patients with $\mathrm{mRCC}$ treated with sorafenib. BMI, body mass index; $\mathrm{CI}$, confidence interval; ECOG, Eastern Cooperative Oncology Group; mRCC, metastatic renal cell carcinoma; MSKCC, Memorial Sloan-Kettering Cancer Center; OS, overall survival; PFS, progression free survival.

\section{Table 3: Summary of common AEs with an incidence of $\geq 1 \%$ for all grades.}

\begin{tabular}{|l|c|c|c|}
\hline \multicolumn{1}{l}{ Adverse events } & $\begin{array}{c}\text { All grades } \\
\boldsymbol{n}(\mathbf{\%})\end{array}$ & $\begin{array}{c}\text { Grade 2 } \\
\boldsymbol{n}(\%)\end{array}$ & $\begin{array}{c}\text { Grades 3-4 } \\
\boldsymbol{n}(\%)\end{array}$ \\
\hline Hand-foot skin reaction & $155(60.5)$ & $65(25.4)$ & $0(0.2)$ \\
\hline Alopecia & $87(34.0)$ & $20(7.8)$ & $3(1.2)$ \\
\hline Rash & $63(24.6)$ & $25(9.8)$ & $9(3.5)$ \\
\hline Diarrhea & $99(38.7)$ & $51(19.9)$ & $0(0.0)$ \\
\hline Constipation & $33(12.9)$ & $7(2.7)$ & $1(0.4)$ \\
\hline Nausea & $49(19.1)$ & $17(6.6)$ & $1(0.4)$ \\
\hline Vomiting & $19(7.4)$ & $5(2.0)$ & $2(0.8)$ \\
\hline Hypertension & $55(21.5)$ & $23(9.0)$ & $1(0.4)$ \\
\hline $\begin{array}{l}\text { Angina pectoris and } \\
\text { myocardial infarction }\end{array}$ & $3(1.2)$ & $2(0.8)$ & $4(1.6)$ \\
\hline Anemia & $41(16.0)$ & $17(6.6)$ & $0(0.0)$ \\
\hline Leukopenia & $7(2.7)$ & $1(0.4)$ & $0(0.0)$ \\
\hline Thrombocytopenia & $4(1.6)$ & $1(0.4)$ & \\
\hline
\end{tabular}

(Continued) 


\begin{tabular}{|c|c|c|c|}
\hline Adverse events & $\begin{array}{c}\text { All grades } \\
n(\%)\end{array}$ & $\begin{array}{c}\text { Grade } 2 \\
n(\%)\end{array}$ & $\begin{array}{c}\text { Grades 3-4 } \\
n(\%)\end{array}$ \\
\hline Mucositis & $46(18.0)$ & $19(7.4)$ & $7(2.7)$ \\
\hline Liver dysfunction & $39(15.2)$ & $17(6.6)$ & $11(4.3)$ \\
\hline Renal dysfunction & $18(7.0)$ & $3(1.2)$ & $1(0.4)$ \\
\hline Albuminuria & $28(10.9)$ & $11(4.3)$ & $5(2.0)$ \\
\hline Gingival hemorrhage & $54(21.1)$ & $12(4.7)$ & $0(0.0)$ \\
\hline Stool hemorrhage & $43(16.8)$ & $11(4.3)$ & $2(0.8)$ \\
\hline Hemoptysis & $27(10.5)$ & $8(3.1)$ & $3(1.2)$ \\
\hline Fatigue & $91(35.5)$ & $32(12.5)$ & $11(4.3)$ \\
\hline Weight loss & $23(9.0)$ & $12(4.7)$ & $1(0.4)$ \\
\hline
\end{tabular}

AEs, adverse events.

Table 4: Prognostic implication of AEs on OS in Chinese patients with $\mathrm{mRCC}$ treated with sorafenib.

\begin{tabular}{|c|c|c|c|}
\hline Adverse events & Number of patients & $\begin{array}{c}\text { Median OS (95\% CI) } \\
\text { (Months) }\end{array}$ & $p$ value \\
\hline \multicolumn{4}{|l|}{ Hand-foot skin reaction } \\
\hline Yes & 155 & $25.5(16.0,35.1)$ & 0.028 \\
\hline No & 101 & $16.7(11.8,21.7)$ & \\
\hline \multicolumn{4}{|l|}{ Alopecia } \\
\hline Yes & 87 & $41.5(25.1,58.0)$ & $<0.001$ \\
\hline No & 169 & $18.4(15.2,21.6)$ & \\
\hline \multicolumn{4}{|l|}{ Rash } \\
\hline Yes & 63 & $37.7(17.2,58.2)$ & 0.018 \\
\hline No & 193 & $20.9(18.0,23.9)$ & \\
\hline \multicolumn{4}{|l|}{ Diarrhea } \\
\hline Yes & 99 & $28.7(17.9,39.5)$ & 0.047 \\
\hline No & 157 & $20.1(13.4,26.8)$ & \\
\hline \multicolumn{4}{|l|}{ Constipation } \\
\hline Yes & 33 & $22.8(15.7,29.8)$ & 0.887 \\
\hline No & 223 & $22.1(20.2,24.1)$ & \\
\hline \multicolumn{4}{|l|}{ Nausea } \\
\hline Yes & 49 & $20.1(18.4,25.0)$ & 0.083 \\
\hline No & 207 & $23.7(18.7,30.4)$ & \\
\hline \multicolumn{4}{|l|}{ Vomiting } \\
\hline Yes & 19 & $15.2(11.1,19.3)$ & 0.011 \\
\hline No & 237 & $24.7(17.4,31.8)$ & \\
\hline \multicolumn{4}{|l|}{ Hypertension } \\
\hline Yes & 55 & $40.1(28.3,53.5)$ & 0.019 \\
\hline No & 201 & $21.1(17.9,24.2)$ & \\
\hline $\begin{array}{l}\text { Angina pectoris and } \\
\text { myocardial infarction }\end{array}$ & & & \\
\hline
\end{tabular}

(Continued) 


\begin{tabular}{|c|c|c|c|}
\hline Adverse events & Number of patients & $\begin{array}{c}\text { Median OS (95\% CI) } \\
\text { (Months) }\end{array}$ & $p$ value \\
\hline Yes & 3 & $3.6(1.3,12.8)$ & 0.217 \\
\hline No & 253 & $22.3(18.2,26.5)$ & \\
\hline \multicolumn{4}{|l|}{ Anemia } \\
\hline Yes & 41 & $19.9(17.9,24.2)$ & 0.126 \\
\hline No & 215 & $23.7(18.9,28.8)$ & \\
\hline \multicolumn{4}{|l|}{ Leukopenia } \\
\hline Yes & 7 & $21.9(18.2,26.5)$ & 0.773 \\
\hline No & 249 & $22.6(18.4,27.3)$ & \\
\hline \multicolumn{4}{|c|}{ Thrombocytopenia } \\
\hline Yes & 4 & $33.3(17.3,55.8)$ & 0.527 \\
\hline No & 252 & $22.1(18.5,25.5)$ & \\
\hline \multicolumn{4}{|l|}{ Mucositis } \\
\hline Yes & 46 & $25.5(9.8,41.3)$ & 0.214 \\
\hline No & 210 & $21.9(16.1,27.6)$ & \\
\hline \multicolumn{4}{|l|}{ Liver dysfunction } \\
\hline Yes & 39 & $31.1(16.8,45.5)$ & 0.109 \\
\hline No & 217 & $22.0(18.3,25.7)$ & \\
\hline \multicolumn{4}{|l|}{ Renal dysfunction } \\
\hline Yes & 18 & $16.9(9.4,24.5)$ & 0.027 \\
\hline No & 238 & $24.6(17.3,32.0)$ & \\
\hline \multicolumn{4}{|l|}{ Albuminuria } \\
\hline Yes & 28 & $18.4(15.5,21.3)$ & 0.046 \\
\hline No & 228 & $24.6(19.9,29.4)$ & \\
\hline \multicolumn{4}{|c|}{ Gingival hemorrhage } \\
\hline Yes & 54 & $24.2(16.9,31.6)$ & 0.173 \\
\hline No & 202 & $21.7(16.9,26.3)$ & \\
\hline \multicolumn{4}{|l|}{ Stool hemorrhage } \\
\hline Yes & 43 & $22.9(16.7,29.9)$ & 0.775 \\
\hline No & 213 & $22.3(18.5,26.1)$ & \\
\hline \multicolumn{4}{|l|}{ Hemoptysis } \\
\hline Yes & 27 & $22.1(12.8,31.2)$ & 0.459 \\
\hline No & 229 & $23.7(18.8,28.7)$ & \\
\hline \multicolumn{4}{|l|}{ Fatigue } \\
\hline Yes & 91 & $20.8(15.9,25.8)$ & 0.108 \\
\hline No & 165 & $25.1(18.4,31.3)$ & \\
\hline \multicolumn{4}{|l|}{ Weight loss } \\
\hline Yes & 23 & $17.5(14.9,20.1)$ & 0.027 \\
\hline No & 233 & $24.9(16.9,32.9)$ & \\
\hline
\end{tabular}

AEs, adverse events; mRCC; metastatic renal cell carcinoma; OS, overall survival. 


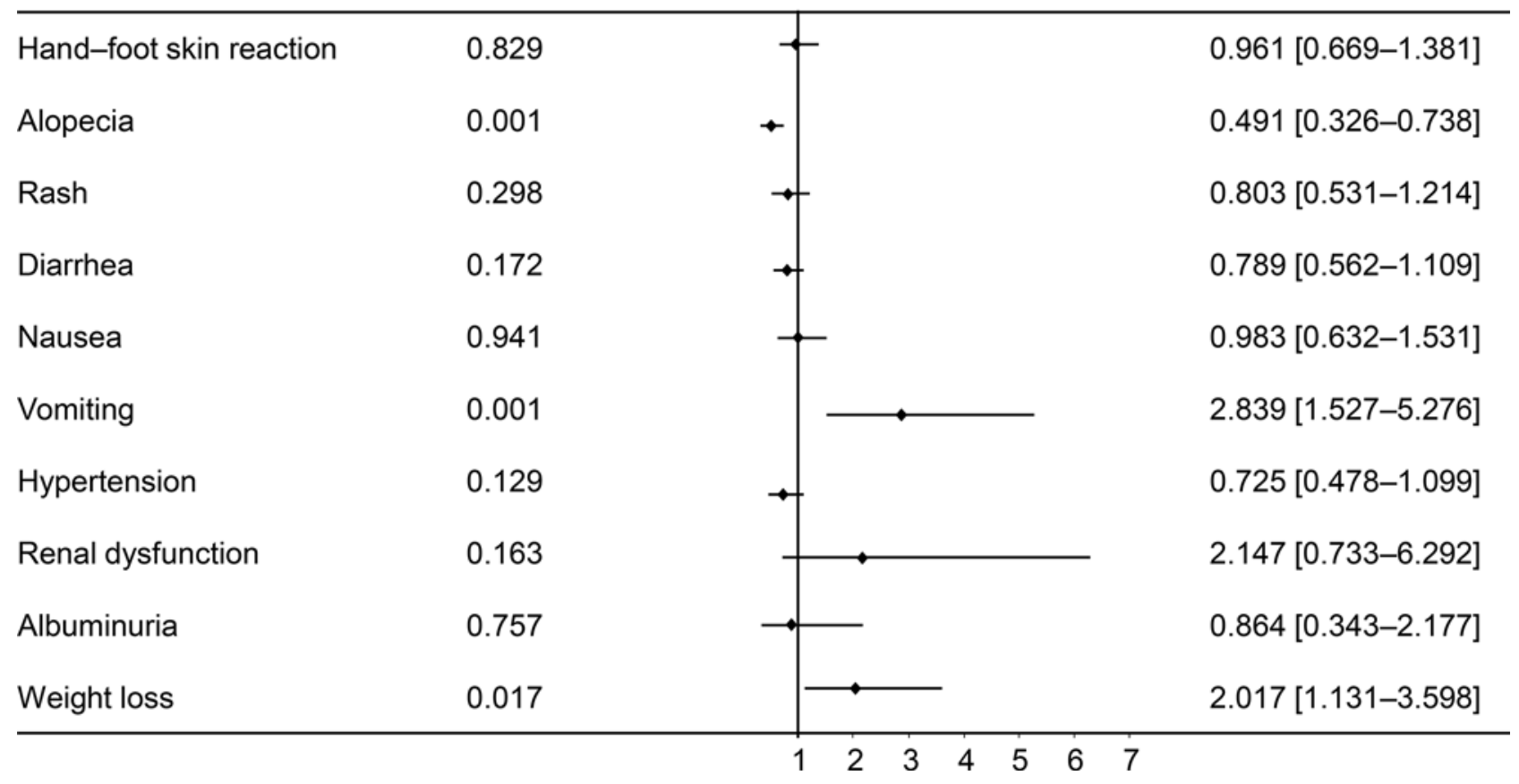

Figure 3: Forest plots displaying multivariate Cox analysis of AEs prognostic to OS in Chinese patients with mRCC treated with sorafenib. AEs, adverse events; BMI, body mass index; CI, confidence interval; ECOG, Eastern Cooperative Oncology Group; mRCC, metastatic renal cell carcinoma; MSKCC, Memorial Sloan-Kettering Cancer Center; OS, overall survival.

metastatic RCC treated with sorafenib $(p \leq 0.05)$. Sorafenib was thus confirmed to be effective in elderly patients, as illustrated in earlier studies [8, 25]. The baseline MSKCC score was also found to be a significant and strong predictor for both PFS and OS. Lower scores predicted improved PFS and OS, while higher scores predicted decreased PFS and OS, suggesting poorer prognosis. Tanigawa et al. [26] also reported favorable prognosis according to the MSKCC risk groups to be a significant and strong factor for predicting superior PFS in patients with advanced RCC on sorafenib treatment from Japan. This observation was earlier attributed to the higher levels of VEGF in patients with higher MSKCC scores compared with patients with lower scores at baseline [9]. The involvement of multiple organs in mRCC in our study significantly predicted reduced PFS and OS, as reported earlier [27]. In addition, the best tumor response was also identified as a significant predictor for improved PFS and $\mathrm{OS}$ in the order of $\mathrm{CR}>\mathrm{PR}>\mathrm{SD}>\mathrm{PD}(p<0.05)$. Furthermore, the time from nephrectomy to sorafenib treatment was also found to be a significant predictor of improved PFS and OS. There was no statistically significant difference in PFS as well as OS when sorafenib is administered as the first-line or second-line treatment after cytokine or sunitinib therapy for mRCC. These results suggest similar benefits of sorafenib in first- and second-line patients as demonstrated earlier in a nonrandomized, open-access trial [16]. AEs were not compared between lines of sorafenib treatment in our study. Expert opinion based on available evidence however suggests similar incidence of AEs in first-line and subsequent lines of sorafenib therapy in patients with mRCC [28].

Although not significant in multivariate regression model, univariate analysis of prognostic demographic variables in our study also indicated high BMI $\left(\geq 23.1 \mathrm{~kg} / \mathrm{m}^{2}\right)$, lower ECOG performance status, clear cell subtype of RCC, lower tumor nucleus grade and time from nephrectomy to sorafenib treatment to be associated with better outcomes including PFS, and/or OS with sorafenib treatment in Chinese patients. Previous studies also reported an association of pre-operative obesity, a cause of $\mathrm{RCC}$, with better prognosis and improved OS in patients with RCC [29, 30]. Several explanations for this were reviewed by these authors, including increased fat between the kidney and Gerota's fascia in obese patients acting as a barrier to further invasion of cancer cells and better nutritional status contributing to improved survival, while cachexia associated with underweight patients predicted poorer prognosis $[29,30]$. This observation is further strengthened by our recent report wherein higher visceral adiposity, a comprehensive indicator of nutritional status and biological factors, was found to correlate strongly with reduced mortality in the patients who received VEGF-targeted therapy [31]. Treatment with sorafenib as an anti-angiogenic agent was earlier suggested to be less effective for non-clear cell subtypes of RCC [32]. As reviewed earlier, deregulated VEGF or mTOR pathways associated with the inactivation of the von Hippel Lindau (VHL) gene are important therapeutic targets in clear 
cell RCC. Improved clinical outcomes with targeted agents including sorafenib were, therefore, advocated in patients with RCC of the clear cell subtype but not the non-clear cell subtype [33]. Lower grade (grade 1-2) of tumors based on necrosis, illustrated to be associated with improved PFS and OS in our study, was earlier reported as an independent predictor [34].

The AE profile in our study, compared with data from patients of western origin reported in the TARGET study, revealed a higher incidence of hand-foot skin reaction $(60.5 \%$ vs. $30 \%)$, alopecia (34\% vs. $27 \%)$, hypertension $(21.5 \%$ vs. $17 \%)$, and anemia (16\% vs. $8 \%)$. However, these results are consistent with the earlier reports on the tolerability of sorafenib in Chinese patients with advanced RCC, as well as in patients with hepatocellular carcinoma in the Asian-Pacific trial [5, 14, 15, 17-20, 35]. This observation may again be attributed to the difference in ethnicity and the associated differences in molecular features as explained earlier. There were also events of bleeding, liver dysfunction, and angina similar to reports from earlier studies in Chinese patients with advanced RCC treated with sorafenib [5, 15, 20]. Univariate analysis of the prognostic significance of AEs encountered in this study with the median OS revealed a significant association of hand-foot skin reaction, alopecia, rash, diarrhea, and hypertension towards improved median OS in Chinese patients treated with sorafenib $(p \leq 0.05)$. Multivariate analysis, however, revealed alopecia to be a significant, independent and strong predictor for improved OS, while vomiting and weight loss were identified as significant predictors for decreased OS. The higher incidence of AEs related to skin reactions and its association with the OS corroborate the findings from earlier studies including pooled safety analyses of sorafenib in the treatment of solid tumors, including RCC, which have demonstrated a significant association of the severity of the skin reactions with the time to progression [5, 36-39]. A single-center retrospective study from Japan suggested that sorafenib induced hand-foot skin reaction was associated with improved best tumor response, and PFS was a useful biomarker of clinical outcome in patients with mRCC [40]. Although continuous dosing of sorafenib in patients with advanced RCC was earlier suggested to be associated with an increased incidence of diarrhea, its prognostic significance related to survival in these patients is lacking $[20,41]$. Diarrhea was, however, suggested to be an independent positive prognostic factor for prolonged OS in patients with hepatocellular carcinoma treated with sorafenib [37, 42, 43]. Our study reported a high incidence of hypertension, mainly Grade 1 or Grade 2. This observation was similar to a previous study that reported a higher incidence of low-grade sorafenib-induced hypertension in Chinese patients with advanced RCC that was managed effectively with antihypertensive therapy, with no reports of associated cardiac events, hypertensive stress, dose reduction, or treatment discontinuation.
Sorafenib-induced hypertension was associated with improved median OS ( $p \leq 0.02)$, although it was not a significant predictor of OS in our study as reported earlier [44]. A systematic review and meta-analysis of studies in cancer patients treated with sorafenib revealed a significantly higher incidence of hypertension in patients with RCC, and the occurrence was further suggested to be associated with improved prognosis [45]. AEs such as vomiting, albuminuria, and weight loss were, however, found to be associated with significantly reduced median OS in our study $(p \leq 0.05)$. Anorexia with or without nausea, vomiting, or diarrhea related to targeted therapies for RCC, presented as dramatic weight loss, was associated with deteriorated quality of life and survival. Albuminuria $\leq$ Grade 2 was reported to be common in patients treated with VEGF inhibition, but is rarely $\geq$ Grade 3 or nephrotic and is suggested to be associated with renal dysfunction and/or hypertension, which in turn may affect OS. Overall, the potential emergence of certain low-grade AEs such as hand-foot skin reactions and hypertension is, therefore, advocated in patients with advanced RCC treated with sorafenib to be associated with improved survival [6, 46-49].

The retrospective design and the sample size of this study may be inadequate to comprehensively determine the prognostic significance of sorafenib on OS in Chinese patients with mRCC.

This study provides a valuable insight into the long-term safety and efficacy of sorafenib as a first-line or second-line therapy to treat advanced RCC in patients from China. The identified significant prognostic baseline predictors for improved clinical outcomes with respect to PFS and/or OS were higher age, low MSKCC score, time from nephrectomy to sorafenib treatment, number of metastatic tumors, and best response. Alopecia, an AE of prognostic significance, was identified as an independent and strong predictor for improved OS, whereas vomiting and weight loss were significant predictors for decreased OS. The identified prognostic factors and AEs will be helpful in establishing realistic patient expectations and in guiding treatment decisions to help the clinicians employ the most suitable treatment strategy involving sorafenib in order to improve the survival in these patients.

\section{MATERIALS AND METHODS}

This retrospective study was approved by the institutional review board of Fudan University, Shanghai Cancer Center, Shanghai, China. Consecutive patients with $\mathrm{mRCC}$ who provided informed consent and were treated with sorafenib were screened in the Department of Urology, Fudan University, Shanghai Cancer Center between April 2006 and May 2013 for inclusion in this study. Adult patients with follow-up data available for at least 1 year with baseline computed tomography (CT) scans that revealed at least one measurable metastatic 
lesion ( $\geq 10 \mathrm{~mm}$ in greatest diameter) and at least one follow-up CT scan after treatment assessed as per the Response Evaluation Criteria In Solid Tumors (RECIST) criteria were included for analysis. Patients who were lost to follow-up were excluded from this study. Patient records were retrospectively reviewed and the $\mathrm{CT}$ scans were reviewed independently by a senior radiologist.

\section{Treatment and follow-up}

Patients were administered sorafenib either as first-line or second-line treatment for $\mathrm{mRCC}$. All patients received oral sorafenib $400 \mathrm{mg}$ twice daily on a continuous dosing schedule, at an interval of 12 hours. Treatment was continued until disease progression or unacceptable toxicity. Dose reduction to $400 \mathrm{mg}$ once daily was allowed for unacceptable toxicities including Grade 3 or 4 hematological toxicity, skin toxicity, hypertension, and/or hepatic dysfunction as defined by the National Cancer Institute's Common Terminology Criteria for Adverse Events (NCI-CTCAE) version 4.0 at the discretion of the attending urologists.

Follow-ups were scheduled for all patients every month during their treatment with sorafenib or every 3 months after the discontinuation of their treatment in case of unacceptable toxicity. Assessments included protocol-mandated evaluation of complete history, physical examination, and routine laboratory tests (complete blood count, serum electrolytes, and liver and renal function tests). Tumor changes were assessed with a CT scan starting at 6 weeks after the initiation of the treatment using the best response as per the RECIST criteria and PFS. Follow-up RECIST measurements were ordered every 6-8 weeks during the treatment and at every follow-up visit after the termination of the treatment.

\section{Outcomes and assessments}

The primary end point was OS (calculated from the date of the first dose of sorafenib to the date of death or last follow-up) and the secondary end point was PFS (time from the first administration of sorafenib to the first documentation of disease progression or death from any cause). The safety outcome measures were incidence of AEs from the first administration of sorafenib to the last follow-up. Exploratory analysis included evaluation of the effect of important prognostic factors such as age, gender, MSKCC score, ECOG performance, previous nephrectomy, previous systemic therapy and number of metastatic tumors with PFS and OS, and the association of AEs with OS.

\section{Statistical analysis}

The statistical analyses of the collected data were performed using SPSS software version 19. Continuous variables such as PFS and OS were reported as medians and interquartile ranges, and categorical data such as age, gender, previous nephrectomy, or systemic therapy were presented as proportions. The follow-up duration was calculated using the reversed Kaplan-Meier method. The Shapiro-Wilk test was used to evaluate the data for normality distribution. OS and PFS were estimated using the Kaplan-Meier method with Rothman's 95\% CI and compared across the groups using the log-rank test. The Cox proportional hazards model was used to evaluate the prognostic value of the investigated parameters. All $p$ values were two-sided and were considered significant if $p$ value was $<0.05$. The concordance index and the proportion of 2 variance explained $(\mathrm{R})$ were computed to assess the prediction performance for survival (PFS, OS).

\section{ACKNOWLEDGMENTS}

This work is supported by the National Natural Science Foundation of China (NSFC) 81202004. The authors acknowledge Rajani Salunke, Ph.D., and Vinitha Senthil, Ph.D., Indegene Lifesystems Pvt. Ltd., for their writing assistance and editorial support.

\section{CONFLICTS OF INTEREST}

The authors indicate no potential conflicts of interest.

\section{REFERENCES}

1. Zhou M, He H. Pathology of renal cell carcinoma; in S.C. Campbell, B.I. Rini (eds): Renal Cell Carcinoma: Clinical Management, Current Clinical Urology. New York, Springer Science+Business Media, 2013, pp 23-41.

2. Choudhary S, Sudarshan S, Choyke PL, Prasad SR. Renal cell carcinoma: recent advances in genetics and imaging. Seminars in Ultrasound, CT and MRI. 2009; 30:315-325.

3. Conti A, Santoni M, Amantini C, Burattini L, Berardi R, Santoni G, Cascinu S, Muzzonigro G. Progress of molecular targeted therapies for advanced renal cell carcinoma. BioMed Research International. 2013; 2013:419176.

4. Wahlgren T, Harmenberg U, Sandstrom P, Lundstam S, Kowalski J, Jakobsson M, Sandin R, Ljungberg B. Treatment and overall survival in renal cell carcinoma: a Swedish population-based study (2000-2008). British Journal of Cancer. 4-16;2013; 108:1541-1549.

5. Ye DW, Zhang HL. Critical appraisal of sorafenib in the treatment of Chinese patients with renal cell carcinoma. OncoTargets and Therapy. 2014; 7:925-935.

6. Eisen T, Sternberg CN, Robert C, Mulders P, Pyle L, Zbinden S, Izzedine H, Escudier B. Targeted therapies for renal cell carcinoma: review of adverse event management strategies. Journal of the National Cancer Institute. 2012; 104:93-113.

7. Hutson TE. Targeted therapies for the treatment of metastatic renal cell carcinoma: clinical evidence. Oncologist. 2011; 16:14-22. 
8. Procopio G, Derosa L, Gernone A, Morelli F, Sava T, Zustovich F, De GU, Ferrari V, Sabbatini R, Gasparro D, Felici A, Burattini L, Calvani N, et al. Sorafenib as firstor second-line therapy in patients with metastatic renal cell carcinoma in a community setting. Future Oncology. 2014; 10:1741-1750.

9. Escudier B, Eisen T, Stadler WM, Szczylik C, Oudard S, Staehler M, Negrier S, Chevreau C, Desai AA, Rolland F, Demkow T, Hutson TE, Gore M, et al. Sorafenib for treatment of renal cell carcinoma: Final efficacy and safety results of the phase III treatment approaches in renal cancer global evaluation trial. Journal of Clinical Oncology. 2009; 27:3312-3318.

10. Motzer R, Eisen T, Hutson TE, Szczylik C, Krygowski M, Strahs AL, Esteves B, Krivoshik AP. Overall survival results from a phase III study of tivozanib hydrochloride versus sorafenib in patients with renal cell carcinoma. 2013 Genitourinary Cancers Symposium. Journal of Clinical Oncology. 2013; 31. suppl: abstract 350.

11. Rini B, Szczylik C, Tannir NM, Koralewski P, Tomczak P, Deptala A, Dirix LY, Fishman M, Ramlau R, Ravaud A, Rogowski W, Kracht K, Sun YN, et al. AMG 386 in combination with sorafenib in patients with metastatic clear cell carcinoma of the kidney: a randomized, doubleblind, placebo-controlled, phase 2 study. Cancer. 2012; 118:6152-6161.

12. International Agency for Research on Cancer. GLOBOCAN. 2012; . Available from: http://globocan.iarc .fr/Default.aspx Accessed June 23, 2015.

13. Beck J, Procopio G, Bajetta E, Keilholz U, Negrier S, Szczylik C, Bokemeyer C, Bracarda S, Richel DJ, Staehler M, Strauss UP, Mersmann S, Burock K, et al. Final results of the European Advanced Renal Cell Carcinoma Sorafenib (EU-ARCCS) expanded-access study: a large open-label study in diverse community settings. Annals of Oncology. 2011; 22:1812-1823.

14. Escudier B, Eisen T, Stadler WM, Szczylik C, Oudard S, Siebels M, Negrier S, Chevreau C, Solska E, Desai AA, Rolland F, Demkow T, Hutson TE, et al. Sorafenib in advanced clear-cell renal-cell carcinoma. New England Journal of Medicine. 2007; 356:125-134.

15. Guo F, Xie X, Liu Z, Song X, Zhang Q, Kong X, Li C, Li Z. Prognostic analysis of Chinese patients with metastasic renal cell cancer ( $\mathrm{mRCC}$ ) receiving sorafenib: A multicenter retrospective study. 2013 Genitourinary Cancers Symposium. Journal of Clinical Oncology. 2013; 31. suppl: abstract e15582.

16. Stadler WM, Figlin RA, McDermott DF, Dutcher JP, Knox JJ, Miller WH Jr, Hainsworth JD, Henderson CA, George JR, Hajdenberg J, Kindwall-Keller TL, Ernstoff MS, Drabkin HA, et al. Safety and efficacy results of the advanced renal cell carcinoma sorafenib expanded access program in North America. Cancer. 2010; 116:1272-1280.
17. Sun Y, Na Y, Yu S, Zhang Y, Zhou A, Li N, Yang L, Lou G. Sorafenib in the treatment of Chinese patients with advanced renal cell cancer. 2008 Genitourinary Cancers Symposium. Journal of Clinical Oncology. 2008; 26, suppl: abstract 16127.

18. Yang L, Shi L, Fu Q, Xiong H, Zhang M, Yu S. Efficacy and safety of sorafenib in advanced renal cell carcinoma patients: Results from a long-term study. Oncology Letters. 2012; 3:935-939.

19. Ye D, Guo J, Lee J-L, Zhou A-P, Huang Y, Hu Z, Fu C, Liu J. Sorafenib treatment of Asian patients with advanced renal cell carcinoma (RCC) in daily practice: Subset analysis of the large non-interventional PREDICT study. 2013 Genitourinary Cancers Symposium. Journal of Clinical Oncology. 2012; 30. suppl: abstract 4628.

20. Zhang H, Dong B, Lu JJ, Yao X, Zhang S, Dai B, Shen Y, Zhu Y, Ye D, Huang Y. Efficacy of sorafenib on metastatic renal cell carcinoma in Asian patients: results from a multicenter study. BMC Cancer. 2009; 9:249.

21. Jager D, Ma JH, Mardiak J, Ye DW, Korbenfeld E, Zemanova M, Ahn H, Guo J, Leonhartsberger N, Stauch K, Bockenhoff A, Yu J, Escudier B. Sorafenib treatment of advanced renal cell carcinoma patients in daily practice: the large international PREDICT study. Clinical Genitourinary Cancer. 2015; 13:156-164.

22. Stafford HS, Saltzstein SL, Shimasaki S, Sanders C, Downs TM, Sadler GR. Racial/ethnic and gender disparities in renal cell carcinoma incidence and survival. Journal of Urology. 2008; 179:1704-1708.

23. Erdem L, Giovannetti E, Leon LG, Honeywell R, Peters GJ. Polymorphisms to predict outcome to the tyrosine kinase inhibitors gefitinib, erlotinib, sorafenib and sunitinib. Current Topics in Medicinal Chemistry. 2012; 12:1649-1659.

24. Garte $\mathrm{S}$. The role of ethnicity in cancer susceptibility gene polymorphisms: the example of CYP1A1. Carcinogenesis. 1998; 19:1329-1332.

25. Procopio G, Bellmunt J, Dutcher J, Bracarda S, Knox J, Brueckner A, Molnar I, Escudier B, Hutson TE. Sorafenib tolerability in elderly patients with advanced renal cell carcinoma: results from a large pooled analysis. British Journal of Cancer. 2013; 108:311-318.

26. Tanigawa G, Kawashima A, Yamaguchi S, Nishimura K, Miyoshi S, Kajikawa J, Meguro N, Yosioka T, Oka T, Hara T, Takayama H, Nonomura N. Clinical outcome and prognostic factors of sorafenib in Japanese patients with advanced renal cell carcinoma in general clinical practice. Japanese Journal of Clinical Oncology. 2011; 41:1265-1270.

27. Han KR, Pantuck AJ, Bui MH, Shvarts O, Freitas DG, Zisman A, Leibovich BC, Dorey FJ, Gitlitz BJ, Figlin RA, Belldegrun AS. Number of metastatic sites rather than location dictates overall survival of patients with node-negative metastatic renal cell carcinoma. Urology. 2003; 61:314-319. 
28. Bellmunt J, Fishman M, Eisen T, Quinn D. Expert opinion on the use of first-line sorafenib in selected metastatic renal cell carcinoma patients. Expert Rev Anticancer Ther. 2010; 10:825-835.

29. Choi Y, Park B, Jeong BC, Seo SI, Jeon SS, Choi HY, Adami HO, Lee JE, Lee HM. Body mass index and survival in patients with renal cell carcinoma: a clinical-based cohort and meta-analysis. International Journal of Cancer. 2013; 132:625-634.

30. Park B, Jeong BC, Seo SI, Jeon SS, Choi HY, Lee HM. Influence of body mass index, smoking, and blood pressure on survival of patients with surgically-treated, low stage renal cell carcinoma: a 14-year retrospective cohort study. Journal of Korean Medical Science. 2013; 28:227-236.

31. Gu W, Zhu Y, Wang H, Zhang H, Shi G, Liu X, Ye D. Prognostic value of components of body composition in patients treated with targeted therapy for advanced renal cell carcinoma: a retrospective case series. PLoS One. 2015; 10:e0118022.

32. Larkin JM, Eisen T. Renal cell carcinoma and the use of sorafenib. Therapeutics and Clinical Risk Management. 2006; 2:87-98.

33. Kroeger N, Xie W, Lee JL, Bjarnason GA, Knox JJ, Mackenzie MJ, Wood L, Srinivas S, Vaishamayan UN, Rha SY, Pal SK, Yuasa T, Donskov F, et al. Metastatic non-clear cell renal cell carcinoma treated with targeted therapy agents: characterization of survival outcome and application of the International mRCC Database Consortium criteria. Cancer. 2013; 119:2999-3006.

34. Rioux-Leclercq N, Karakiewicz PI, Trinh QD, Ficarra V, Cindolo L, de la TA, Tostain J, Zigeuner R, Mejean A, Patard JJ. Prognostic ability of simplified nuclear grading of renal cell carcinoma. Cancer. 2007; 109:868-874.

35. Pan JJ, Javle M, Thinn MM, Hsueh CT, Hsueh CT. Critical appraisal of the role of sorafenib in the management of hepatocellular carcinoma. Hepatic Medicine: Evidence and Research. 2010; 2:147-155.

36. Cheng AL, Kang YK, Chen Z, Tsao CJ, Qin S, Kim JS, Luo R, Feng J, Ye S, Yang TS, Xu J, Sun Y, Liang H, et al. Efficacy and safety of sorafenib in patients in the AsiaPacific region with advanced hepatocellular carcinoma: a phase III randomised, double-blind, placebo-controlled trial. Lancet Oncology. 2009; 10:25-34.

37. Gollob JA, Rathmell WK, Richmond TM, Marino CB, Miller EK, Grigson G, Watkins C, Gu L, Peterson BL, Wright JJ. Phase II trial of sorafenib plus interferon alfa-2b as first- or second-line therapy in patients with metastatic renal cell cancer. Journal of Clinical Oncology. 2007; 25:3288-3295.

38. Llovet JM, Ricci S, Mazzaferro V, Hilgard P, Gane E, Blanc JF, de Oliveira AC, Santoro A, Raoul JL, Forner A, Schwartz M, Porta C, Zeuzem S, et al. Sorafenib in advanced hepatocellular carcinoma. New England Journal of Medicine. 2008; 359:378-390.
39. Strumberg D, Awada A, Hirte H, Clark JW, Seeber S, Piccart P, Hofstra E, Voliotis D, Christensen O, Brueckner A, Schwartz B. Pooled safety analysis of BAY 43-9006 (sorafenib) monotherapy in patients with advanced solid tumours: Is rash associated with treatment outcome? European Journal of Cancer. 2006; 42:548-556.

40. Nakano K, Komatsu K, Kubo T, Natsui S, Nukui A, Kurokawa S, Kobayashi M, Morita T. Hand-foot skin reaction is associated with the clinical outcome in patients with metastatic renal cell carcinoma treated with sorafenib. Japanese Journal of Clinical Oncology. 2013; 43:1023-1029.

41. Edeline J, Vauléon E, Rioux-Leclercq N, Perrin C, Vigneau C, Bensalah K, Laguerre B. Safety and Efficacy of Sorafenib in Renal Cell Carcinoma. Cancer Growth and Metastasis. 2012; 5:35-47.

42. Bettinger D, Schultheiss M, Knuppel E, Thimme R, Blum HE, Spangenberg HC. Diarrhea predicts a positive response to sorafenib in patients with advanced hepatocellular carcinoma. Hepatology. 2012; 56:789-790.

43. Iavarone M, Cabibbo G, Piscaglia F, Zavaglia C, Grieco A, Villa E, Camma C, Colombo M. Field-practice study of sorafenib therapy for hepatocellular carcinoma: a prospective multicenter study in Italy. Hepatology. 2011; 54:2055-2063.

44. Yang L, Ding Y, Shi L, Yu S. Management of hypertension induced by sorafenib in advanced renal cell carcinoma. Tumor. 2012; 32:380-383.

45. Li Y, Li S, Zhu Y, Liang X, Meng H, Chen J, Zhang D, Guo H, Shi B. Incidence and risk of sorafenib-induced hypertension: a systematic review and meta-analysis. Journal of Clinical Hypertension. 2014; 16:177-185.

46. Costero O, Picazo ML, Zamora P, Romero S, Martinez-Ara J, Selgas R. Inhibition of tyrosine kinases by sunitinib associated with focal segmental glomerulosclerosis lesion in addition to thrombotic microangiopathy. Nephrology Dialysis Transplantation. 2010; 25:1001-1003.

47. Izzedine H, Massard C, Spano JP, Goldwasser F, Khayat D, Soria JC. VEGF signalling inhibition-induced proteinuria: Mechanisms, significance and management. European Journal of Cancer. 2010; 46:439-448.

48. Okuno Y, Kume H, Hosoda C, Homma Y. Development of nephrotic syndrome after administration of sorafenib in a case of metastatic renal cell carcinoma. Case Reports in Medicine. 2011; 2011:710216.

49. Tesarova P, Tesar V. Proteinuria and hypertension in patients treated with inhibitors of the VEGF signalling pathway - incidence, mechanisms and management. Folia Biologica. 2013; 59:15-25. 